\title{
Maqasid Al Syari'ah: Melacak Gagasan Awal
}

\author{
Nispan Rahmi \\ Mahasiswa Pasca Sarjana Universitas Islam Negeri Antasari, Banjarmasin \\ Jurusan Ilmu Syariah \\ e-Mail: nispan.rahmi@gmail.com
}

\begin{abstract}
This study discusses the tracing of the initial idea of maqasid sharia. Based on authentic and valid data concerning some of Umar bin Khatthab's policies based on the consideration of al maslahah al 'ammah, the spirit / embryo of the studies of the theory of maqasid al shariah has existed since the early development of Islam, ie the period of Companions especially in the era of al khulafa' al rasyidun. The next era of study related maqasid al shariah was continued by $\mathrm{Al}$ Tirmizi al Hakim (w.296 H / 908 AD), Abu Zayd al Balkhi (322 H / 933M), Al Qaffal al Kabir Syaybi (365 H / 975 AD), al Amiri al Faylasuf (w.381 H / 991 CE). The next period of study maqasid al sharia is increasingly focused which is characterized by the emergence and the frequent use of the term maqasid al sharia and its substance as well.
\end{abstract}

Keywords: Methods, history, law, ushul, maqasid, shari'ah

Abstrak: Penelitian ini membahas tentang melacak gagasan awal maqasid syariah. Berdasarkan data-data otentik dan valid mengenai beberapa kebijakan Umar bin Khatthab r.a yang didasarkan atas pertimbangan al maslahah al 'ammah, roh/ embrio kajian-kajian teori maqasid al syariah telah ada sejak awal perkembangan Islam, yakni masa sahabat khususnya pada era al khulafa' al rasyidun. Era berikutnya studi terkait maqasid al syariah dilanjutkan oleh Al Tirmizi al Hakim (w. 296 H/ 908 M), Abu Zayd al Balkhi (w. 322 H/ 933M), Al Qaffal al Kabir Syayhi (w. 365 H/ 975 M), al Amiri al Faylasuf (w. $381 \mathrm{H} / 991 \mathrm{M}$ ). Masa- masa berikutnya kajian maqasid al syariah sudah semakin fokus yang ditandai dengan muncul dan seringnya menggunakan istilah maqasid al syariah dan substansinya sekaligus.

Kata Kunci: Metode, sejarah, hukum, ushul, maqasid, syariah

\section{Pendahuluan}

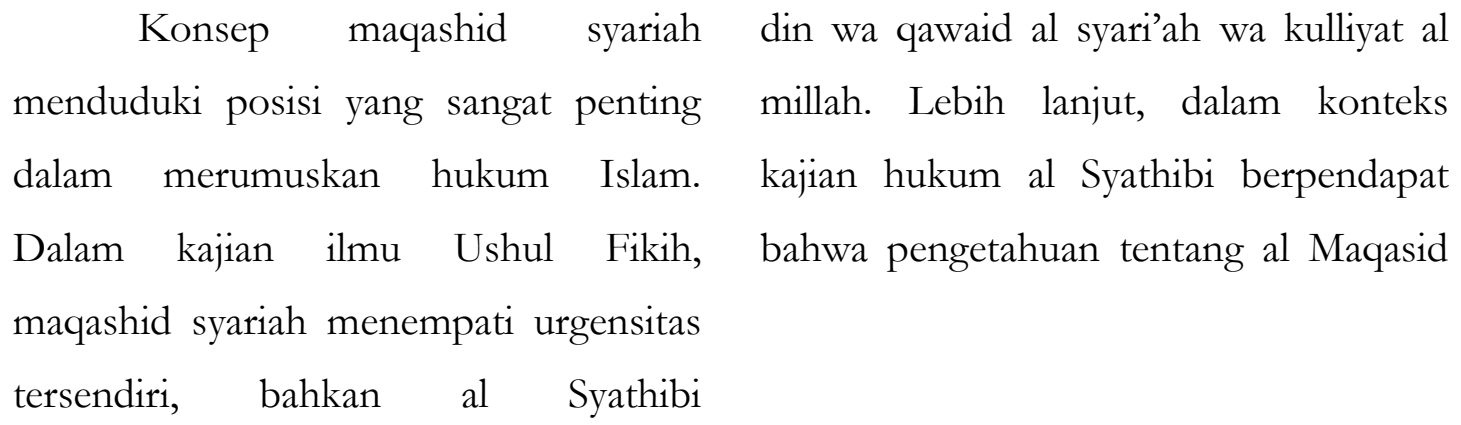


Jurnal Syariah: Jurnal Ilmu Hukum dan Pemikiran

adalah syarat utama bagi keahlian ijtihad, mujtahid, pada segala tingkatan.

\section{Abdul Wahhab Khallaf} menyatakan bahwa nash-nash syariah tidak dapat difahami secara tepat dan benar kecuali oleh seseorang yang mengetahui maqashid syariah dan asbab al nuzul. Bahkan Fathi al Daraini, penulis buku al Fiqh al Islam al Muqarin Ma'a al Mazhab, mengatakan bahwa pengetahuan tentang maqashid syariah merupakan pengetahuan yang berdiri sendiri dan memiliki proyeksi masa depan dalam rangka pengembangan teori ushul fiqh. ${ }^{2}$ Sebenarnya, studi maqashid syariah telah lama berlangsung, dalam kajian sejarah pemikiran hukum Islam klasik, esensi maqashid syariah telah dibahas oleh banyak ulama sejak masa awal perkembangan Islam.

${ }^{1}$ Seperti dikutip oleh Jaser 'Audah dalam Al Maqasid Untuk Pemula, penjt. 'Ali 'Abdelmon'im, (Yogyakarta: SUKA-Pres UIN Sunan Kalijaga, 2013), hal. 46-47; bandingkan dengan Agustianto Mingka, Maqashid Syariah dalam Ekonomi dan Kenangan Syariah, (Jakarta: Ttp, tt.), hal, 1.

${ }^{2}$ Agustianto Mingka, ibid.
Maqasid al-Syariah ..160-178

Nispan Rabmi

Makalah ini mencoba untuk menelusuri konsep maqashid syariah yang diduga kuat telah berlangsung sejak masa awal itu, yang dituangkan dalam sebuah tema " Maqashid al Syariah: Melacak Gagasan Awal.

\section{Pengertian Maqasid al Syariah}

Istilah al Maqasid adalah bentuk jama' dari kata 'maqsid', yang menunjuk kepada tujuan (al hadaf), sasaran (al garad), hal yang diminati (al matlub), atau tujuan akhir (al gayah). ${ }^{3}$ Maqasid al Syariah berarti tujuan akhir dari syariat atau hukum Islam.

Ibnu 'Asyur di dalam Maqashid Al-Syariah Al-Islamiyah, menyatakan bahwa Maqashid Syari'ah adalah maknamakna dan hikmah-hikmah yang diperlihatkan oleh Allah Subhanahu wa Ta'ala dalam semua atau sebagian besar syari'at-Nya, juga masuk dalam wilayah ini sifat-sifat syariat atau tujuan umumnya. Menurut Ibnu Asyur, inti dari maqashid syari'ah adalah untuk

3Jaser 'Audah, Al Maqasid Untuk Pemula, penjt. 'Ali 'Abdelmon'im, (Yogyakarta: SUKAPres UIN Sunan Kalijaga, 2013), hal. 6. 
mencapai kemaslahatan umat yang sebesar-besarnya, karena tujuan penetapan hukum dalam Islam adalah untuk menciptakan kemaslahatan dalam rangka memelihara tujuantujuan syara'.

Hampir senada dengan Ibnu Asyur, Wahbah Zuhaili menyatakan syariat itu pada dasarnya untuk mewujudkan tujuan umum, kemashlahatan 'ammah, dalam alam nyata yaitu membahagiakan individu dan jama'ah, memelihara aturan serta menyemarakkan dunia dengan segenap sarana yang akan menyampaikannya kepada kesempurnaan, kebaikan, budaya, dan peradaban yang terpuji. ${ }^{4}$ Dari sini jelas bahwa dakwah Islam itu merupakan rahmat bagi umat manusia, sebagaimana dinyatakan oleh Allah dalam al Qur'an surat al Anbiya' (21): 107. Untuk mencapai tujuan umum, maslahat 'ammah, ini Islam datang membawa ajarannya sebagai berikut:

${ }^{4}$ Wahbah Zuhaili, Nazariat al Darurah al Syar'iyyah, Muqaranah Ma'a al Qanun al Wad'I, edisi Indonesia, Konsep Darurat da;lam Hukum Islam, terj. Said Agil Hasan al Munawwar dan M. Hadri Hasan, Jakarta: Gaya Media Pratama, 1997), hal. 47.
1. Islam menetapkan dalam undang-undang dasarnya prinsip menghindari kesempitan dan menolak mudarat. Berdasarkan prinsip ini, maka Islam menetapkan wajib berlaku adil dan bermusyawrah, memelihara hak, menyampaikan amanah, dan kembali kepada ulama untuk menjelaskan pendapat yang benar dalam menghadapi kasus-kasus kontemporer.

2. Mementingkan pembinaan mental individu sehingga ia menjadi sumber kebaikan bagi masyarakat. ${ }^{5}$ Karena apabila individu menjadi baik dengan sendirinya masyarakat akan baik pula.

3. Prinsip memelihara kemaslahatan manusia dalam kehidupan dunia dan akhirat. $\mathrm{Al}$ Syathibi berkata: 'Sesungguhnya penetapan berbagai ketentuan hukum syariat itu tidak lain adalah bertujuan untuk mencapai kemaslahatan-kemaslahatan hambahamba Allah untuk masa sekarang dan

5 Muhammad Abu Zahrah, Ushul al Fiqh, (Beirut: Dar al Fikr al Arabi, tt.), hal. 350 
masa yang akan datang. ${ }^{6} \mathrm{Hal}$ ini tentunya didasarkan pada hasil penelitian mendalam (istiqrab) dan pengamatan terhadap ketentuan-ketentuan syariat. Berdasarkan itu, jelaslah bahwa semua ketentuan hukumnya ditetapkan demi kemaslahatan hamba-hamba-Nya.

\section{Gagasan Awal: Melacak Sejarah dalam Pembentukan Karakter Hukum}

Uraian tersebut menunjukkan bahwa inti dari maqashid al syariah adalah mewujudkan kemaslahatan umat secara menyeluruh, dunia maupun akhirat. Dari sini akan terlihat bahwa kajian-kajian tentang maqashid al syariah itu rukhnya (baca, embrionya) telah ada sejak masa awal Islam berkembang, terutama pada masa/ generasi sahabat khususnya pada masa al khulafa' al rasyidun.

Apa yang dilakukan Umar bin Khatthab misalnya, tidak bisa dilupakan begitu saja dalam hubungannya dengan studi-studi maqashid al syariah

6 Abu Ishak al Syathibi Ibrahim bin Musa al Maliki, al Muwafaqat fi Usbul al Syariah, Jild II (Beirut: Dar al Kutub al Ilmiah, tt.), hal. 6. kemudiannya. Ia memberikan inspirasi dalam menangkap pesan-pesan atau rahasia-rahasia dibalik pensyariatan ketentuan-ketentuan hukum Allah. Berikut akan dipaparkan beberapa kebijakan Umar ra yang didasarkan pada pertimbangan kemaslahatan umum, al mashlahah al 'ammah.

1. Awal Abad Pertama Hijriah

Umar Bin Khatthab

Misalnya kasus kodifikasi al Qur'an, dimana Umar bin Khattab menyaksikan realitas di depan mata banyaknyapenghapal al Qur'an, khuffaz, menjadi syuhada dalam perang Yamamah, dengan mempertimbangkan secara teliti kebaikan dan atau kemaslahatan umat sekarang dan yang akan datang, maka Umar menemui Abu Bakar, saat itu menjabat sebagai khalifah pertama, mengajukan usul agar segera memerintahkan kodifikasi al Qur'an.

Dalam kasus ini, imam Bukhari meriwayatkan sebuah hadis dalam kitab Shahibnya, bahwa Zaid bin Tsabit r.a menceritakan kesaksiannya sendiri sebagai berikut: "Disaat berkecamuknya 
perang Yamamah, Abu Bakar minta supaya aku datang kepadanya. Setibanya aku di rumahnya, kulihat Umar bin al Khatthab sudah berada di sana. Abu Bakar lalu berkata: 'Umar datang kepadaku melaporkan bahwa perang Yamamah bertambah sengit dan banyak para penghafal al Qur'an yang gugur. Ia khawatir jika peperangan yang dahsyat itu akan mengakibatkan lebih banyak lagi khuffaz yang gugur. Karena itu, ia berpendapat sebaiknaya aku segera memerintahkan kodifikasi al Qur'an'. Kukatakan kepada Umar: 'Bagaimana mungkin kita melakukan sesuatu yang tidak dilakukan oleh Rasulullah SAW?! Umar menjawab: 'Demi Allah, itu (kodifikasi al Qur'an) adalah kebajikan, ‘kemaslahatan'.Umar berulang-ulang mendesak dan pada akhirnya Allah membukakan dadaku sehingga aku sependapat dengannya".

Dalam kesaksian itu, Zaid bin Tsabit lebih jauh mengatakan: "Kepadaku Abu Bakar berkata: 'Kamu seorang muda, cerdas dan terpercaya. Dahulu kamu bertugas sebagai pencatat wahyu, membantu Rasulullah SAW.Dan seterusnya kamu mengikuti al Qur'an, karena itu laksanakanlah tugas menghimpun (kodifikasi) al Qur'an. Demi Allah, kata Zaid lebih lanjut, seumpama orang membebani kewajiban kepadaku untuk memindahkan sebuah gunung, kurasa tidak lebih berat dari pada perintah kodifikasi al Qur'an yang diberikan kepadaku! Kukatakan kepada Abu Bakar r.a. :'Bagaimana kita boleh melakukan suatu pekerjaan yang tidak dilakukan oleh Rasulullah?!' Abu Bakar menjawab: 'Demi Allah, pekerjaan itu adalah kebajikan/ 'kemaslahatan'! Abu Bakar terus-menerus mengimbau sampai Allah membukakan dadaku sebagaimana Allah telah membukakan dada Abu Bakar dan Umar. . " "7

Dalam riwayat tersebut Umar mengajukan usul kodifikasi al Qur'an

${ }^{7}$ Abu Abdillah Muhammad bin Ismail al Bukhari, Shabih al Bukhari, III, (Bandung: Diponegoro, t.t.), hal. 2068-2069; Al Hafiz Ahmad bin Ali bin Hajar al Asqalani, Fath al Bari Syarh Shahih al Bukhari, juz XI, (Beirut: Dar al Kutub al Ilmiah:tt. ), hal. 12- 13; Shubhi al Shalih, Mabahis fi 'Ulum al Qur'an, (Beirut: Dar al Ilmi li al Malayin, 1995), hal. 85; M.M. al A'zami, The History of The Qur'anic Text: From Revelation to Compilation, Edisi tarjmh. Sejarah Teks al Qur'an: Dari Wahyu sampai Kompilasi, (Jakarta: Gema Insani, 2005), hal. 84. 
dengan alasaan kebaikan/ kemaslahatan, خير , dengan kalimat itu ia meyakinkan khalifah Abu Bakar ketika beliau ini merespon usul Umar dengan mengatakan:

\section{كيف تفعل شيئاً لم يفعله رسول الله صلى}

bagaimana kita melakukan , الله عليه وسلم sesuatu yang Rasulullah SAW sendiri tidak melakukannya. Dengan kalimat itu juga Abu Bakar ketika meyakinkan Zaid bin Tsabit selaku kordinator tim pengkodifikasian al Qur'an. Sudah diketahui orang kalimat al khair dalam riwayat tersebut berari al faidah, ${ }^{8}$ bermanfaat.Dan al faidah sendiri berarial mashlahah. ${ }^{9}$ Dengan demikian, kodifikasi al Qur'an dalam pandangan Umar bin al Khatthab mengandung kermanfaatan dan kemaslahatan bagi umat sekarang dan yang akan datang.

Kasus berikutnya mengenai hukum perang, dimana seperti dipraktikkan Nabi Muhammad SAW, jika suatu suku tertentu tidak menyerah

88 Ahmad Warson Munawwir, Al Munawwir, Kamus Arab Indonesia, (Surabaya: Pustaka Progressif, 1997), hal. 378.

9 Ahmad Warson Munawwir, ibid.hal 789. secara damai tetapi melalui pertempuran, maka tanah mereka disita sebagai harta rampasan perang dan dibagi-bagikan kepada pasukan kaum Muslimin. Mungkin sekali praktek yang seperti ini merupakan hukum perang di masa itu.Tetapi kaum Muslimin memandang praktek ini sebagai SunnabNabi, sebagai bagian dari mekanisme untuk menghancurkan musuh dan untuk memberikan imbalan kepada pejuangpejuang Muslim.Hukum ini ternyata tetap berlaku ketika kaum Muslimin melakukan penaklukan-penaklukan dalam ukuran kecil diluar Arab. Tetapi ketika Irak (Sawad)danMesir ditaklukkan dan dijadikan daerah kekuasaan Islam pada masa ia berkuasa, Umar tidak mau merampas tanah yang luas ini dari penghuni-penghuninya yang sediakala dan tidak membagi-bagikannya kepada pasukan-pasukan Arab. Walaupun bukan Umar sendiri yang berpendirian demikian dan banyak pula orang-orang terkemuka lainnya yang sependapat, namun ia mendapat tantangan yang keras. 
Tantangan ini menjadi sedemikian kerasnya sehingga berkembanglah semacam krisis.Tetapi Umar tetap kokoh mempertahankan pendiriannya dan mengatakan jika pasukan-pasukan Arabmenjadi pemilikpemilik tanah, maka mereka tidak akan menjadi pejuang-pejuang lagi walaupun sesungguhnya, seperti yang ternyata dikemudian hari, pertimbanganpertimbangannya adalah berdasarkan perasaan keadilan sosial-ekonomi

Pada suatu hari terbaca oleh Umar ayat al-Qur'an berikut ini yang secara garis besarnya mendukung pendapatnya dan memperkuat keyakinannya yang kokoh terhadap keadilan:

\section{“... Dan orang-orang yang} datang setelah mereka akan berkata: 'Ya Allah! Ampunilah kami bersama saudara-saudara seagama kami yang terdahulu .... Sesungguhnya Engkau "Maha Pengasih dan Penyayang".(AlQur'an, 59:10).

Ayat ini dengan jelas sekali menunjukkan bahwa yang menjadi motivasi Umar adalah pertimbanganpertimbangan keadilan sosial-ekonomi dan ia tidak mau membiarkan negerinegeri yang luas dibagi-bagikan kepada pasukan Arab Muslim sehingga penduduk beserta generasi-generasi dikemudian hari terbengkalai. ${ }^{10}$ Dengan demikian, aspek maslahah yang meliputi keadilan sosial dan ekonomi bagi masyarakat Irak dan Mesir beserta keturunannya menjadi alasan kuat bagi Umar untuk tidak membagi-bagikan tanah atau daerah taklukan perang kepada para pasukan.Dalam kasus ini Umar juga menetapkan kewajiban membayar kharaj, ${ }^{11}$ semacam jizyah yang gugur kewajibannya dengan keislaman mereka, bagi masyarakat penggarap tanah tersebut kepada negara sebagai sewa tanah dan jaminan keamanan mereka tetap tinggal dalam kekuasaan Islam

${ }^{10}$ Fazlur Rahman, Islamic Methodology in History, Edisi terj.Membuka pintu Ijtihad, pentri.Anas Mahyuddin, (Bandung: Pustaka, 1984), hal. 272-273.

11 Sayyid Sabiq,Figh al Sunnah, III, (TTP. : Dar al Fikr,1983.), hal. 91. 
Kasus yang lain adalah tentang ketentuan mengucapkan talaq dengan tiga kali berturut-turut, maka di masa Nabi SAW, masa Abu Bakar, dan masamasa awal pemerintahan Umar dihukumkan jatuh sebagai talaq satu. Belakangan Umar bin al Khatthab menetapkan tiga kali ucapan talaq dengan tiga kali talaq sebagai hukuman dan pelajaran bagi masyarakatnya. ${ }^{12}$ Dengan demikian, mereka tidak mainmain dengan ucapan tiga kali talaq.Itulah ijtihad beliau.Beliau menetapkan seperti itu bertujuan untuk membina kemaslahatan/ kepentingan umum yang dipandangnya tepat pada saat itu.Karena itu, sekalipun demikian tidak boleh meninggalkan fatwa Rasulullah yang diikuti para sahabat di masa Nabi dan masa khalifah Umar sendiri.

Dalam bidang hukum kriminal, jarimah budud, sudah termasyhur bahwa khalifah Umar bin Khatthab menagguhkan hukuman had, yakni potong tangan bagi kejahatan pencurian,

12 Sayyid Sabiq, Figh al Sunnah, II, (TTP. : Dar al Fikr,1983.), hal. 231.. karena pertimbangan musim paceklik yang sedang menimpa masyarakat.

Dalam bidang legislasi sosial, Khalifah Umar bin al Khatthab memberikan instruksi bahwa; "Setiap anak yang dilahirkan seorang budak perempuan dari tuannya tidak boleh dijual, dihadiahkan, atau diwaariskan oleh tuannya.Ia (si budak perempuan) adalah milik tuannya selama tuannya masih hidup (kecuali jika ia dimerdekakan oleh tuannya) tetapi ketika tuannya mati maka secara otomatis ia memperoleh kemerdekaannya."13

Sebelum Umar tidak ada diambil langkah legislatif untuk menjamin bahwa "um al-walad" (ibu si anak) tidak diperjualbelikan, dihadiahkan atau dipertahankan sebagai hamba setelah tuannya mati. Setelah tuannya mati si hamba beserta anaknya harus menikmati kemerdekaan yang sama. Apakah yang telah terjadi sejak masa hidup Nabi sehingga sebuah kebiasaan yang didukung oleh persetujuannya yang

${ }^{13}$ Fazlur Rahman, Islamic Methodology. . . , Op. Cit., hal. 275. 
"tidak diucapkan" (Sunnab Sukutiyah) harus ditentang melaui legislasi? Disini jelas sekali bahwa esensi Islam sedang dipertaruhkan, dan apabila kita tinjau dengan lebih cermat ternyata pada masa Umar itu sebuah masalah besar mengenai keadilan social timbul karena berbagai faktor baru didalam masyarakat.

Semakin banyaknya jumlah budak-budak lelaki dan perempuan menimbulkan berbagai masalah.Yang sangat gawat diantara semuanya adalah sehubungan dengan hamba-hamba perempuan, yang jumlah nya sangat besar, yang melahirkan anak.Jika mereka ini diperjualbelikan dan dihadiahkan, maka apakah akibatnya terhadap masyarakat?Yang lebih penting lagi apakah akibatnya terhadap anak-anak mereka, terhadap pribadi dan moral anak-anak tersebut?

Inilah pertimbangan yang meyebabkan Umar akhirnya melarang hamba-hamba perempuan diperjual belikan dan dipertahankan sebagai hamba setelah tuannya mati. Karena ia melahirkan anak-anak tuannya, maka selama tuannya masih hidup, kesejahteraannya dianggap selalu diperhatikan oleh tuannya itu. Jadi Umar mrngurangi "hak-hak" dari para pemilik budak; bahkan ia melanggar sebuah Sunnah untuk menjaga agar landasanlandasan Sunnah tetap bidup, kuat dan semakin berjaya.

Itulah beberapa riwayat dan fakta otentik (shahih) mengenai kebijakan Umar bin Khatthab yang didasarkan pada kemaslahaatan umum, yang merupakan inti dari tujuan-tujuan syariat yang akan dicapai. Secara dhabir kebijakan Umar tersebut dianggap kontradiktif dengan sunnah yang berlaku, tetapi tidak demikian adanya karena Umar dihadapkan pada situasi dan kondisi yang berbeda dengan yang terjadi pada masa Nabi. Umar justru mampu menangkap pesan-pesan dari sebuah teks yang dihubungkan dengan fakta dan situasi di masyarakat.Kemampuan dan keberanian Umar dalam mengambil keputusan dengan metoda seperti itutelah menginspirasi kajian-kajian hukum berikutnya.Ia merupakan embrio 
Jurnal Syariah: Jurnal Ilmu Hukum dan Pemikiran
Maqasid al-Syariah ..160-178

Nispan Rabmi lahirnya studi maqashid al syariah yang digagas oleh ulama kemudian.

\section{Abad Ke-3 H Sampai Menjelang} Akhir Abad Ke-4 H

Setelah masa sahabat, teori dan klasifikasi al maqasid mulai berkembang. Akan tetapi seperti kata Jaser 'Audah, al Maqasid, sebagaimana kita kenal sekarang, tidak kunjung matang sebelum masa para ulama Ushuluddin; yakni antara abad ke-5 sampai abad ke- $8 \mathrm{H}$. Meski demikian, selama tiga abad pertama, gagasan tentang tujuan/ maksud, atau yang dikenal dengan istilah hikmah, 'ilal, munasabat, atau ma'ani, telah muncul di dalam berbagai metode berpikir yang digunakan oleh para imam klasik hukum Islami. ${ }^{14}$

Istilah-istilah terkait pemikiran al Maqasid ini muncul pada penerapan metode-metode fikih seperti qiyas, istihsan, (preferensi kehakiman), dan maslahah. Meski itu, al Maqasid belum tampak sebagai wilayah studi fikih tersendiri sebelum berakhirnya abad ke 3
H. Setelah itu pengembangan teori "jenjang keniscayaan” (al darurab), oleh Imam

al Juwayni (w. 478 H/ 1085 M) muncul pada abad ke-5 H. Berikut penjelasan sekilas mengenai konsepkonsep dini al Maqasid antara abad ke-3 dan abad ke-5 H.

a. Al Tirmizi al Hakim (w. 296 H/ $908 \mathrm{M})$

Seperti dijelaskan Jaser 'Audah, al Tirmizi menulis naskah pertama yang diketahui didedikasikan untuk topik al Maqasid. Dalam naskah tersebut, istilah 'al Maqasid' sendiri terlihat pada judulnya, yakni al Salah wa Maqasiduha. Buku itu berisi penelusuran hikmah dan rahasia spiritual di balik setiap gerakan dan zikir salat, dengan penjelasan sangat sufistik. ${ }^{15}$ Contoh dalam buku itu al Maqasiddari salat; seperti "penegasan kerendah-hatian" sebagai maksud dibalik pengagungan Allah SWT dalam setiap gerakan salat. 
Jurnal Syariah: Jurnal Ilmu Hukum dan Pemikiran Vol 17, Nomor 2 Desember 2017
Maqasid al-Syariah ..160-178

Nispan Rabmi b. Abu Zayd al Balkhi (w. $322 \mathrm{H}$ / $933 \mathrm{M})$

Al Bakhi penulis naskah pertama tentang al Maqasid dalam ranah muamalat.Beliau memberi judul bukunya al Ibnah 'an ilal al Diyanah.Dalam karyanya itu, al Balkhi menelusuri tujuan-tujuan di balik hukum-hukum islami. Karya senada berjudul Masalih al Abdan wa al Anfus; pada buku ini beliau membahas bagaimana praktik agama Islam dan hukum-hukumnya berdampak positif terhadap fisik dan kejiwaan. ${ }^{16}$.

c. Al Qaffal al Kabir Syayhi (w. 365 $\mathrm{H} / 975 \mathrm{M}$ )

Jaser 'Audah menjelaskan, al Qaffal menulis manuskrip tertua tentang al Maqasid yang ditemukan di Dar al Kutub Kairo, Mesir. Manuskrip berjudul Mahasin al

Syara'i (Keindahan-keindahan tujuan-tujuan Syariat) menjelaskan secara singkat setiap aturan dan tujuan serta hikmah dibaliknya. Sistematika pembahasan dalam manuskrip ini seperti sistematika fikih klasik yang dimulai dengan taharah, wudu, dst. Manuskrip ini setebal 400 halaman. ${ }^{17}$

Pengembangan konsep-konsep al Daruriyat, al Siyasah, dan al Makrumat oleh al Qaffal dalam manuskripnya itu merupakan langkah awal yang memperhalus jalan bagi al Juwayni dan al Gazali dalam mengembangkan teori fikih mazhab Syafi'i dan teori al Maqasidnya; di mana keduanya mengembangkan ketiga konsep al Qaffal itu untuk mengemukakan konsep al daruriyyat, al hajiyat, dan al tabsiniyyat.

Pasca al Qaffal dilanjutkan Ibnu Babawayh al Qummi (w. 381 H/ 991 M).Ulama ternama abad ke-4 $\mathrm{H}$ bermazhab Syiah ini, sebagai orang pertama di kalangan Syiah yang membahas tentang al Maqasid dalam bukunya 'Ilal al Syar'i18 (Sebab musabab di balik tujuan-tujuan Syariat), meski sebagian peneliti mengklaim bahwa kajian al Maqasid sebelum abad ke-20, hanya terbatas pada kalangan Sunni.Namun faktanya tidak demikian. 'Ilal al Syar'i menjelaskan rasionalisasi

16 Jaser 'Audah,Ibid., hal. 31.

17 Jaser 'Audah, Ibid., hal. 32.

18 Jaser 'Audah, Ibid, hal. 35. 
moral terhadap salat, puasa, haji, zakat, dst.

Studi terkait al Maqasid juga dilakukan oleh al Amiri al Faylasuf (w. 381 H/ 991 M) dalam bukunya al I'lam bi Manaqib al Islam.Karya ini membahas klasifikasi teoritis tujuan-tujuan Syariat terbatas pada sisi hukum pidana Islam, al budud.

Jaser 'Audah 'mensinyalir' meski melangkah dengan pasti, perkembangan al Maqasid menuju klasifikasi jenjang kebutuhan tidak mencapai bentuk bulatnya sebelum abad ke-5 $\mathrm{H}$, teori al Maqasid baru tampak matang pada abad ke-8 H.

\section{Al Maqasid (Abad Ke-5 H sampai} Abad Ke-8 H)

Tentang Metode-metode harfiah dan nominal yang dikembangkan sampai dengan abad ke-5 $\mathrm{H}$ terlihat tidak sanggup menghadapi kerumitan hidup dan perkembangan peradaban.Teori al maslahah al mursalah telah dikembangkan sebagai sebuah metode yang meliputi 'apa yang tidak disebutkan dalam teks-teks suci'.Teori tersebut telah mengisi kekosongan pada metode- metode harfiah, dan akhirnya, melahirkan teori al Maqasid dalam disiplin ilmu dan praktik hukum Islami.

Para ulama fikih yang paling berpengaruh dalam teori al Maqasid antara abad ke-5 dan ke-8 $\mathrm{H}$ adalah Abu al Ma'ali al Juwayni (w. 478 H/ 1085 M), Abu Hamid al Gazali (w. 505 H/ 1111 M), al 'Izz ibn 'Abd al Salam (w. 660 H/ 1209 M), Syihab al Din al Qarafi (w. 684 H/ 1285 M), dan Syamsuddin ibn al Qayyim (w. 748 H/ 1347 M), dan al Syathibi (w. 790 H/ 1388 M). Berikut uraian singkat peran masing-masing mereka.

1. Imam al Juwayni Pencetus Teori 'Kebutuhan Publik'

Abu al Ma'ali al Juwayni menulis buku al Burhan fi Usul al Figh (Bukti Nyata tentang Asas Metode Hukum Islam).Buku tersebut dianggap sebagai karya fikih pertama yang mengemukakan sebuah teori tentang 'jenjang-jenjang kebutuhan dasar' dalam nuansa makna yang kita kenal saat ini. Al Juwayni menyarankan 5 jenjang al Maqasid, yaitu: 
al darurat, al hajat al 'ammah, al makrumat, al mandubat, dan 'apa

yang tidak dapat dikembalikan kepada maksud yang spesifik. ${ }^{19} \mathrm{Al}$ Juwayni juga menjelaskan bahwa tujuan hukum Islam adalah al ismah, proteksi yang nyata, terhadap keimanan, jiwa, akal, ranah-ranah kepribadian, dan harta.

Karya al Juwayni yang juga signifikan dalam upaya pengembangan teori al Maqasid adalah Giya al Umam (Penyelamat Umat-umat).

2. Imam al Gazali pencetus 'Jenjangjenjang Keniscayaan’

Sebagai seorang murid al-Juwayni, Abu Hamid al Gazalimengembangkan teori gurunya dalam bukunya alMustasfa(Sumber yang Murni).Diawali dengan mendefinisikan al Maslahah, yang berarti suatu ibarat menarik manfaat dan menolak mafsadat, kemudaratan.Dan yang dihendaki dengan pemaknaan tersebut bahwa menarik manfaat dan menolak kemudaratan itu adalah maksud-maksud makhluk itu sendiri.Dan kemaslahatan

${ }^{19}$ Jaser 'Audah, Ibid, hal. 38. makhluk merupakan hasil dari tujuantujuan akhirnya. Dengan demikian, kata al Gazali, kemaslahatan dalam konteks tersebut adalah memelihara tujuantujuan syariat.

Dan tujuan-tujuan syariat dari pada makhluk itu ada 5 macam, yakni: (1) memelihara keimanan (agama), (2) jiwa, (3) akal, (4) keturunan, dan (5) harta. $^{20}$ Walaupun mengemukakan analisis yang cukup mendalam, al Gazali enggan untuk memberikan sifat hujizyyah (sifat untuk dalil yang dapat berdiri sendiri) terhadap satupun al-Maqasid yang Beliau ajukan.Bahkan, beliau menyebutkannya sebagai al-masalih almawhumah (maslahat-maslahat terduga). ${ }^{21}$

Alasan dibalik tanggapan 'terduga', yang dicirikan kepada konsep al-Maqasid menurut al-Gazali, adalah sifat dasar konsep itu sebagai hasil telaah manusiawi dalam teks suci, bukan sebagai bagian dari teks-teks itu yang wajib diterapkan selayaknya sebagai tujuan Syariat yang jelas dan nyata.

\footnotetext{
${ }^{20}$ Husin Hamid Hasan, Nazariat al Maslahah fi al Fiqh al Islami, (Kairo: Dar al Nahdah al 'Arabiah, 1971), hal. 5-6.

21 Jaser 'Audah, Op. Cit., hal. 40.
} 
3. Al-'Izz ibn 'Abd al-Salam dan 'Hikmah di Balik Hukum Syariat'

Al-'Izz ibn 'Abd al-Salam (w.660 H/1209 M) menulis 2 buku kecil tentang al-Maqasid yang bernuansa 'Hikmah di balik aturan Syariat': yaitu: Maqasid al-Salah (Tujuan-tujuan Pokok Salat) dan Maqasid al-Sawn (Tujuantujuan Pokok Puasa). ${ }^{22}$

Akan tetapi, sumbangansumbagan besar Beliau dalam mengembangkan teori al-Maqasid adalah karyanya tentang kemaslahtankemaslahatan, yang diberi judul Qawa'id al-Abkam fi Masalih al-Anam (Kaidahkaidah Dasar tentang Kemaslahatankemaslahatan Manusia).

Dalam karyanya itu, disamping pembahasannya yang luas tentang maslahat dan mudarat, al-'Izz menghubungkan kesahan aturan dengan tujuannya dan hikmah dibaliknya.

4. fgvImam al Qarafi

Sebagaimana dikutip oleh Jaser 'Audah, Syihab al Din al Qarafi juga memberikan kontribusi dalam pengembangan teori al Maqasid, melalui teori klasifikasi terhadap perbuatan Nabi SAW berdasarkan niat/ maksud dari Nabi sendiri yang dikembangkannya, al Qarafi dalam al Furuqnya menyatakan:

“'Terdapat perbedaan antara tindakan-tindakan Nabi SAW dalam kapasitasnya sebagai utusan ilahi, sebagai hakim, atau sebagai pemimpin, . . . Implikasi hukum dari perbedaanperbedaan itu adalah bahwa apa yang dilakukan Nabi sebagai utusan adalah kaidah umum dan permanen ... (Akan tetapi) keputusan-

keputusan yang berhubungan dengan militer, kepercayaan public, ... menunjuk para hakim dan gubernur, membagi rampasan perang, dan menandatangani kesepakatan internasional . . adalah aturan yang menyangkut para pemimpin saja. ${ }^{23}$

Al Qarafi juga menulis tentang Fath al Zarai, pembukaan sarana untuk mencapai maslahat; teori ini sebagai bentuk perluasan teori al Maqasidnya.Menurutnya, segala sarana yang menyampaikan kepada tujuan yang legal perlu dibuka, sebaliknya, sarana

${ }^{23}$ Jaser 'Audah, Ibid, hal. 43. 
yang menyampaikan kepada yang illegal, harus ditutup.

5. Imam Ibnu Qayyim al Jawziyah

Syamsuddin Ibnu Qayyim al Jawziyah, bermazhab Ahmad bin Hanbal, juga berkontribusi dalam pengembangan teori al Maqasid melalui kritik beliau yang mendalam terhadap praktik al hiyal, fiksi hukum/ rekayasa hukum. Al Hiyal adalah sesuatu yang dijadikan sebagai perantara untuk menghalalkan yang diharamkan. Menurut Ibnu al Qayyim, hukum itu tidak bisa berubah dengan cara merubah bentuk, haiatnya, dan penggantian namanya. ${ }^{24}$ Karena itu, orang-orang Yahudi ketika Allah mengharamkan kepada merekalemak bangkai, mereka mencairkannya, menjualnya, kemudian memanfaatkan harganya, Allah melaknat mereka melalui lisan Rasulillah SAW tentang siasat, hilah, yang telah mereka lakukan, karena melihat tujuannya. Dan hukum haramnya itu tidak berbeda,

${ }^{24}$ Syamsuddin Abi Abdillah Muhammad bin Abi Bakr bin Ayyub, yang dikenal dengan Ibnu Qayyim al Jawziyah, I'lam al Muwaqqi'in 'an Rabb al 'Alamin, (Beirut: Dar al Kutub al Ilmiah, tt), hal. 545 . apakah lemak itu berbentuk padat maupun berbentuk cair. Menurut Ibnu Qayyim, siasat yang demikian, termasuk perbuatan yang mendurhakai dan menipu Allah dan Rasul-Nya. Perbuatan tersebut nyata sekali tidak terdapat di dalam syariat, ${ }^{25}$ justru berlawanan dengan maksud syariat.

Ibnu al Qayyim kemudian menjelaskan kesempurnaan dan maksud syariat Islam yang bertolak belakang dengan praktik dan maksud al hiyal.Maha suci Allah yang telah mewajibkan beberapa kewajiban, mengharamkan beberapa yang diharamkan, mewajibkan terlaksananya hak demikemaslahatan hidup hambahamba-Nya baik di dunia maupun di akhirat.Allah telah menjadikan syariatNya yang sempurna ini sebagai pedoman bagi manusia, aturan untuk menjaga kelangsungan hidup, obat penawar untuk menghilangkan berbagai penyakit, sebagai pelindung orang yang meminta perlindungan dengannya, dan sebagai perisai yang menyelamatkan orang yang

${ }^{25}$ Ibnu Qayyim al Jawziyah, Ibid, hal. 546. 
berlindung di dalamnya dari berbagai macam kejahatan. ${ }^{26}$ Dia memerintahkan segala kemaslahatan, melarang segala kerusakan, membolehkan segala yang baik, dan mengharamkan segala yang buruk, . . . syi'arnya kejujuran, tiangnya adalah hak, mizannya keadilan, dan hukumnya rinci, sehingga tidak memerlukan penyempurnaan yang bersifat politis oleh para penguasa, dan siasatnya orang-orang yang melakukan siasat. ${ }^{27}$ Demikianlah pernyataan imam Ibnu al Qayyim.

\section{Imam al Syathibi}

Abu Ishaq al Syathibi Ibrahim bin Musa al Maliki (w. 790 H/ 1388 M), seorang penganut mazhab Maliki, dianggap telah berhasil merekonstruksi al Maqasid sebagai asas-asas hukum Islam. Seperti ditulis Jaser 'Audah, al Syathibi dengan bukunya al Muwafaqat fi Ushul al Syariah telah memberikan sumbangan besar dalam

26 Ibnu Qayyim al Jawziyah, Ibid, hal. 598.

27 Ibnu Qayyim al Jawziyah, Ibid, hal. mengembangkan teori al Maqasid dengan melakukan 3 transformasi penting, yakni: Pertama, al Maqasid yang pada era sebelumnya hanya masuk pada kajiankajian 'maslahat-maslahat lepas', di tangan al Syathibi masuk ke "asas-asas bukum". Kedua, al Maqasid yang semula dari 'bikmah di balik aturan', ditransformasikan kepada 'dasar aturan'. Al Syathibi mengklasifikasi teks kepada dua bagian utama; al kulliyat, nas-nas berkenaan pokok-pokok agama, dam al juz'iyyat, nas/ teks berkenaan detil-detil agama. $A l$ Kulliyat mempunyai supremasi atas teksteks al juz'iyyat. Al Maqasid termasuk al kulliyyat, dengan pandangan seperti ini, maka aturan manapun yang dibuat tidak atas nama Syariat tidak dapat melangkahi al Maqasid. Ketiga, al Maqasid dari 'ketidaktentuan' menuju ke ‘keyakinan'. Demikian, selintas teori al Maqasid perspektif al Syathibi. Kajian lebih dalam dan fokus tentang ini akan dibahas oleh pemakalah lain pada minggu-minggu berikutnya.

\section{Kesimpulan}


1. Berdasarkan data-data otentik (w. 748 H/ 1347 M), dan al Syathibi (w. dan valid mengenai beberapa kebijakan $790 \mathrm{H} / 1388 \mathrm{M})$.

Umar bin Khatthab r.a yang didasarkan atas pertimbangan al maslahah al 'ammah, roh/ embrio kajian-kajian teori maqasid al syariah telah ada sejak awal perkembangan Islam, yakni masa sahabat khususnya pada era al khulafa' al rasyidun.

2. Era berikutnya studi terkait maqasid al syariah dilanjutkan oleh $\mathrm{Al}$ Tirmizi al Hakim (w. 296 H/ 908 M), Abu Zayd al Balkhi (w. 322 H/ 933M), Al Qaffal al Kabir Syayhi (w. 365 H/ 975 M), al Amiri al Faylasuf (w. 381 H/ $991 \mathrm{M})$.

3. Masa-masa berikutnya kajian maqasid al syariah sudah semakin fokus yang ditandai dengan muncul dan seringnya menggunakan istilah maqasid al syariah dan substansinya sekaligus. Dan sederet ulama yang paling berpengaruh pada era ini antara lain: Abu al Ma'ali al Juwayni (w. 478 H/ 1085 M), Abu Hamid al Gazali (w. 505 H/ 1111 M), al 'Izz ibn 'Abd al Salam (w. 660 H/ 1209 M), Syihab al Din al Qarafi (w. $684 \mathrm{H} /$ 1285 M), dan Syamsuddin ibn al Qayyim

\section{DAFTAR PUSTAKA}

Abu Ishak al Syathibi Ibrahim bin Musa al Maliki, al Muwafaqat fi Ushul al Syariah, Jild II Beirut: Dar al Kutub al Ilmiah, tt.

Ahmad Warson Munawwir, Al Munawwir, Kamus Arab Indonesia, Surabaya: Pustaka Progressif, 1997.

Agustianto Mingka, Maqashid Syariah dalam Ekonomi dan Keuangan Syariah, Jakarta: Ttp, tt..

Al Hafiz Ahmad bin Ali bin Hajar al Asqalani, Fath al Bari Syarh Shahih al Bukhari, juz XI, Beirut: Dar al Kutub al Ilmiah:tt.

Fazlur Rahman, Islamic Methodology in History, Edisi terj.Membuka pintu Ijtihad, pentrj. Anas Mahyuddin, Bandung: Pustaka, 1984. 
Husin Hamid Hasan, Nazariat al Maslahah fi al Fiqh al Islami, Kairo: Dar al Nahdah al 'Arabiah, 1971.

Jaser 'Audah dalam Al Maqasid Untuk Pemula, penjt. 'Ali 'Abdelmon'im, (Yogyakarta: SUKA-Pres UIN Sunan Kalijaga, 2013).

M.M. al A'zami, The History of The Qur'anic Text: From Revelation to Compilation, Edisi tarjmh. Sejarah Teks al Qur'an: Dari Wahyu sampai Kompilasi, Jakarta: Gema Insani, 2005.

Muhammad Abu Zahrah, Usbul al Fiqh, (Beirut: Dar al Fikr al Arabi, tt.), hal. 350

Muhammad bin Ismail al Bukhari, Abu Abdillah, Shabih al Bukhari, III, Bandung: Diponegoro, t.t.

Sayyid Sabiq, Fiqh al Sunnah, III, TTP. : Dar al Fikr,1983.

Sayyid Sabiq, Fiqh al Sunnah, II, TTP. : Dar al Fikr,1983.

Shubhi al Shalih, Mabahis fi 'Ulum al Qur'an, (Beirut: Dar al Ilmi li al Malayin, 1995.
Wahbah Zuhaili, Nazariat al Darurah al Syar'iyyah, Muqaranah Ma'a al Qanun al Wad'I, edisi Indonesia, Konsep Darurat da;lam Hukum Islam, terj. Said Agil Hasan al Munawwar dan M. Hadri Hasan, Jakarta: Gaya Media Pratama, 1997. yang dikenal dengan Ibnu Qayyim al Jawziyah, I'lam al Muwaqqi'in 'an Rabb al 'Alamin, Beirut: Dar al Kutub al Ilmiah, tt.

Syamsuddin Abi Abdillah Muhammad bin Abi Bakr bin Ayyub, 
Jurnal Syariah: Jurnal Ilmu Hukum dan Pemikiran Vol 17, Nomor 2 Desember 2017
Maqasid al-Syariah ..160-178

Nispan Rabmi 